\title{
Adsorption of water vapour and the specific surface area of arctic zone soils (Spitsbergen)
}

\author{
Jolanta Cieśla*, Zofia Sokołowska, Barbara Witkowska-Walczak, and Kamil Skic \\ Institute of Agrophysics, Polish Academy of Sciences, Doświadczalna 4, 20-290 Lublin, Poland
}

Received October 10, 2016; accepted June 20, 2017

\begin{abstract}
A b s t $\mathrm{r}$ a $\mathrm{c}$ t. Water vapour/nitrogen adsorption were investigated and calculated the specific surface areas of arcticzone soil samples (Turbic Cryosols) originating from different micro-relief forms (mud boils, cell forms and sorted circles) and from different depths. For the characterisation of the isotherms obtained for arctic soils, the Brunauer-Emmet-Teller model was then compared with the two other models (Aranovich-Donohue and Guggenheim-Anderson-de Boer) which were developed from Brunauer-Emmet-Teller. Specific surface area was calculated using the Brunauer-Emmet-Teller model at $\mathrm{p} \mathrm{p}_{0}{ }^{-1}$ range of 0.05-0.35 for the water vapour desorption and nitrogen adsorption isotherms. The values of total specific surface area were the highest in Cryosols on mud boils, lower on cell forms, and the lowest on sorted circles. Such tendency was observed for the results obtained by both the water vapour and nitrogen adsorption. The differences in the values of specific surface area at two investigated layers were small. High determination coefficients were obtained for relationships between the specific surface areas and contents of clay and silt fraction in Cryosols. No statistically significant correlation between the total carbon amount and the values of specific surface area in Cryosols has been found.

K e y w o r d s: specific surface area, arctic zone, Cryosols
\end{abstract}

\section{INTRODUCTION}

Soil formation processes are long-lasting and depend on many factors, the main being climate and humidity. Humidity conditions in soils exert a decisive influence on the thermal and mechanical properties which shape the temperature in the soil profile (Kutilek and Nielsen, 2010; Lal and Shukla, 2004). Due to global warming, especially in this region, conditions have been very good recently for the notation of the first stages of soil formation in the polar zone. Climate change began to be noticed around the mid-19th century, and collected data shows that tem-

*Corresponding author e-mail: j.ciesla@ipan.lublin.pl perature rises are very small in the equatorial regions and increase with latitudes, both north and south. For example, in Central Europe, the average temperature increased by 1.1-1.3 ${ }^{\circ} \mathrm{C}$, whereas within the Arctic Circle, at latitudes ranging from 70 to $90^{\circ}$, the average rise was $2.1^{\circ} \mathrm{C}$ between 1880 and 2004 (Kutilek and Nielsen, 2015; Trenberth et al., 2007; Ziaja, 2004). One of such places is Svalbard Archipelago and its largest island, Spitsbergen. This arctic island is characterised by a mild climate, since it is influenced by the Gulf Stream. The average temperature in July is $5^{\circ} \mathrm{C}$, whereas in January and February, the temperature ranges between -8 and $-16^{\circ} \mathrm{C}$. Annual precipitation is about $400 \mathrm{~mm}$. The recent rise in air temperature is the reason for the sudden thawing of glaciers and the extensive exposure of the terrain underneath. The various cryogenic processes in these places, i.e. frost segregation, swelling, freezing and cracking, formed various micro-relief surface forms (Klimowicz et al., 2013). The next step in the development of the polar terrain is the formation of the initial soils called Cryosols.

Spitsbergen Island is a place of extensive climate change research (Angiel, 1994; Bockheim, 1980; Tedrow, 1977; Washburn, 1980). The static and dynamic water characteristics of the arctic initial soils of Spitsbergen were determined by Melke et al. (2013) and Witkowska-Walczak et al. (2014). Another property of soil which seems to be very important in terms of characteristics is specific surface area (Dziadowiec et al., 1994; Stanich, 2013; Szymański et al., 2013; Walker, 2012). Many researchers have attempted to measure surface area as a means of better describing the investigated soil material, or gaining a better understanding of a particular process or reaction.

(C) 2018 Institute of Agrophysics, Polish Academy of Sciences 
There is a significant relationship between surface area and the various chemical and physical properties of particular soils (Petersen et al., 1996; Sokołowska et al., 2004). For mineral soils, for example, there exists a linear relationship between specific surface area and the content of particular granulometric fractions, the cation exchange capacity and the organic carbon content (Ding Fei et al., 2013; Skic et al., 2016 Sokołowska, 2011; Sokołowska et al., 2009; Xiaojun Zhu et al., 2014). The specific surface area of a soil is the combined surface area of all the particles in the sample, as determined by the employed experimental technique, per unit mass of the sample. As its definition implies, the term 'specific surface area' is an operational concept.

The aim of this paper was to characterise the process of water vapour adsorption on the surface of arctic soils by using different models, as well as to discuss the relationship between the estimated specific surface area and other physical properties of soils which were formed in various micro-relief conditions.

\section{MATERIAL AND METHODS}

The area of research covers the NW part of the Wedel Jarlsberg Land, Spitsbergen $\left(77^{\circ} 26^{\prime}, 7^{\circ} 35^{\prime} \mathrm{N}\right.$ and $13^{\circ} 55^{\prime}$, $\left.14^{\circ} 54^{\prime} \mathrm{E}\right)$ (Klimowicz et al., 2013). Specific surface area was determined for the soils formed on three characteristic micro-relief surface forms, i.e.:

- mud boils, circular and inconsiderable raised forms with a diameter of 50 to $70 \mathrm{~cm}$,

- cell forms, flat 4-6th-wall polygons with a diameter of 50 to $100 \mathrm{~cm}$,

- sorted circles, very expressive forms with a diameter of 100 to $300 \mathrm{~cm}$.

Soil pits were made and profiles were described according to the WRB classification system (Jahn et al., 2006). The investigated soil profiles represented the following groups according to the WRB (IUSS Working Group WRB, 2007):
- Turbic Cryosols (Siltic, Skeletic) in mud boils,

- Turbic Cryosols (Siltic, Skeletic) in cell forms,

- Turbic Cryosols (Skeletic) in sorted circles.

The samples were taken from $0-5 \mathrm{~cm}$ and $10-15 \mathrm{~cm}$ depth of soil. The basic properties of the investigated soil materials (Table 1) were measured using standard methods, i.e. grain composition was determined using the laser diffraction method (Ryżak and Bieganowski, 2013), organic carbon $\left(C_{\text {org. }}\right)$ - using the oxidation method developed by Tiurin, and total carbon content $\left(\mathrm{C}_{\text {total }}\right)$ was determined using the TOC Jena apparatus on the Multi NC2000 carbon analyser (Analytik Jena, module for liquid samples, platinum catalyser, furnace temperature $800^{\circ} \mathrm{C}$ ). Concentrations were calculated automatically on the basis of an 8-point calibration curve. The results were averaged. The calibration standards were prepared on the basis of a concentrated solution of potassium hydrogen phthalate.

The adsorption-desorption isotherms of water vapour in $\mathrm{p}_{0}{ }^{-1}$ ranging from 0.00 to 0.95 were determined according to the Polish standard (PN-Z-19010-1, 1999). Experiments were carried out in triplicate at a temperature of $20.0 \pm 0.5^{\circ} \mathrm{C}$. The variation in replicated data did not exceed $\pm 5 \%$ at the lowest vapour pressure and $\pm 1 \%$ at the highest vapour pressure. The averaged values were used to perform further calculations and to prepare the figures. The Brunauer-Emmet-Teller (BET) (Brunauer et al., 1938), Aranovich and Guggenheim-Anderson-de Boer (GAB) (Anderson, 1946; Van den Berg, 1984) models were used for the description of the water vapour adsorptiondesorption processes (Table 2). The matching of the models to the experimental data was defined by the values of determination coefficient $\left(\mathrm{R}^{2}\right)$ and root mean squared error (RMS).

The adsorption isotherms of nitrogen at $80 \mathrm{~K}$ were obtained using a Sorptomatic 1999, made by Fisons apparatus. Before adsorption measurement, the samples were dried at $105^{\circ} \mathrm{C}$ and outgassed. Measurements for each sample were

T a b l e 1. Basic properties of investigated soil

\begin{tabular}{|c|c|c|c|c|c|c|c|}
\hline \multirow{4}{*}{$\begin{array}{l}\text { Micro-relief } \\
\text { forms }\end{array}$} & \multirow{4}{*}{$\begin{array}{l}\text { Depth } \\
(\mathrm{cm})\end{array}$} & \multicolumn{6}{|c|}{ Grain size distribution (\%) } \\
\hline & & Clay & Silt & Sand & $\begin{array}{c}\text { Gravel and } \\
\text { stones }\end{array}$ & $C_{\text {org. }}$ & $C_{\text {total }}$ \\
\hline & & \multicolumn{4}{|c|}{ Fractions $(\mathrm{mm})$} & \multirow{2}{*}{\multicolumn{2}{|c|}{$\left(\mathrm{mg} \mathrm{g}^{-1}\right)$}} \\
\hline & & $<0.002$ & $0.002-0.05$ & $0.05-2$ & $>2$ & & \\
\hline Mud boils & \multirow{3}{*}{$0-5$} & 10 & 63 & 27 & 32 & 8.3 & 21.52 \\
\hline Cell forms & & 5 & 60 & 35 & 26 & 8.5 & 20.14 \\
\hline Sorted circles & & 4 & 34 & 62 & 29 & 8.9 & 39.96 \\
\hline Mud boils & \multirow{3}{*}{$10-15$} & 10 & 73 & 17 & 21 & 12.0 & 20.70 \\
\hline Cell forms & & 5 & 55 & 40 & 30 & 10.0 & 18.08 \\
\hline Sorted circles & & 4 & 37 & 59 & 22 & 11.3 & 38.04 \\
\hline
\end{tabular}


T a b l e 2. Formulas used to describe adsorption isotherms

\begin{tabular}{ll}
\hline Model & Equation \\
\hline BET (Brunauer et al., 1938) & $N=N_{m} \mathrm{C}\left(\mathrm{pp}_{0}^{-1}\right)\left[\left(1-\left(\mathrm{pp}_{0}^{-1}\right)\right)+(\mathrm{C}-1)\left(1-\left(\mathrm{pp}_{0}^{-1}\right)\right)\left(\mathrm{pp}_{0}^{-1}\right)\right]^{-1}$ \\
$\begin{array}{l}\text { Aranovich (Aranovich, 1991; } \\
\text { Aranovich and Donohue, 1995) }\end{array}$ & $N=N_{m} \mathrm{C}\left(\mathrm{pp}_{0}^{-1}\right)\left[\left(1-\left(\mathrm{pp}_{0}^{-1}\right)\right)^{0.5}+(\mathrm{C}-1)\left(1-\left(\mathrm{pp}_{0}^{-1}\right)\right)^{0.5}\left(\mathrm{pp}_{0}^{-1}\right)\right]^{-1}$ \\
& $N^{-1} \mathrm{pp}_{0}^{-1}=\alpha^{2} \mathrm{p}_{0}^{-2}+\beta \mathrm{pp}_{0}^{-1}+\gamma$ \\
$\begin{array}{l}\text { GAB (Anderson, 1946; } \\
\text { van den Berg, 1984) }\end{array}$ & $\alpha=(1-\mathrm{C})\left(N_{m} \mathrm{C}\right)^{-1} \mathrm{k}$ \\
& $\beta=(\mathrm{C}-2)\left(N_{m} \mathrm{C}\right)^{-1}$ \\
& $\gamma=\left(N_{m} \mathrm{Ck}\right)^{-1}$ \\
\hline
\end{tabular}

$N$ - amount of adsorbed water $\left(\mathrm{g} \mathrm{g}^{-1}\right) ; N_{m}$ - monolayer capacity $\left(\mathrm{g} \mathrm{g}^{-1}\right) ; \mathrm{p}$ - equilibrium pressure of adsorbate; $\mathrm{p}_{0}$ - saturation pressure of adsorbate; $\mathrm{C}, \alpha, \beta, \gamma, \mathrm{k}$ - constants.

replicated three times. The estimated precision of all the measurements was better than $0.5 \%$, and the greatest errors were observed at the highest relative pressures.

The specific surface area $(S)$ of the investigated soils was calculated using the BET model (Brunauer et al., 1938) at $\mathrm{p} \mathrm{p}_{0}^{-1}$ ranged from 0.05 to 0.35 (Gregg and Sing, 1978) for $\mathrm{H}_{2} \mathrm{O}$ desorption $\left(S_{\mathrm{H}_{2} \mathrm{O}}\right)$ and $\mathrm{N}_{2}$ adsorption $\left(S_{\mathrm{N}_{2}}\right)$ isotherms. The following relationship was used:

$$
S=N_{m} M^{-1} \mathrm{~L} \omega,
$$

where: $\mathrm{L}$ is the Avogadro number (6.02 $10^{23}$ molecules per mole), $M$ is the molecular mass of water or nitrogen (in gram per mole), and $\omega$ is the molecule cross-sectional area $\left(10.810^{-20} \mathrm{~m}^{2}\right.$ for $\mathrm{H}_{2} \mathrm{O}$ and $16.410^{-20} \mathrm{~m}^{2}$ for $\left.\mathrm{N}_{2}\right)$.

The total specific surface area $\left(S_{\text {total }}\right)$ was obtained from the relationship (PN-Z-19010-1, 1999):

$$
S_{\text {total }}=2 S_{\mathrm{H}_{2} \mathrm{O}}-\mathrm{S}_{\mathrm{N}_{2}} \text {. }
$$

The calculations and statistical analysis were done using MS Office Excel 2013.

\section{RESULTS AND DISCUSSION}

The adsorption of water vapour and nitrogen in arctic soils as a function of the relative pressure of the applied gas is shown in Fig. 1. For both $\mathrm{H}_{2} \mathrm{O}$ and $\mathrm{N}_{2}$ adsorption, the amount of adsorbate, which was immobilised by solid phase at a given $\mathrm{p} \mathrm{p}_{0}{ }^{-1}$, was the highest for Cryosols from mud boils, and the lowest for those from sorted circles. Adsorption was slightly higher for Cryosols from cell forms than for those from sorted circles, but this was more clearly visible for $\mathrm{H}_{2} \mathrm{O}$ adsorption than for $\mathrm{N}_{2}$ adsorption. Moreover, adsorption varied according to the depth from which the samples were collected. In the case of water vapour, adsorption on mud boils was higher for samples taken from $10-15 \mathrm{~cm}$ than for samples collected from $0-5 \mathrm{~cm}$. For cell forms, a reverse relationship was found, and no differences were observed for sorted circles. The nitrogen adsorption for all micro-relief forms was higher on samples collected from $10-15 \mathrm{~cm}$ than on samples taken from $0-5 \mathrm{~cm}$.
The sigmoid shape of water vapour adsorption and desorption isotherms reflects type II physisorption according to the IUPAC classification (Sing et al., 1985). This kind of isotherm is usually well described by the BET equation (Brunauer et al., 1938). However, we proposed to check the applicability of two other models, which were derived from BET, for the characterisation of isotherms obtained for arctic soils. The BET theory describes a multi-layer physical adsorption. The molecules of adsorbate occupy well-defined sites on the adsorbent surface (one per molecule). After the creation of the first monolayer of adsorbate, the next one is built on it, but there are no interactions between the individual adsorption layers. Each layer can be described by the Langmuir theory. The number of layers of the adsorbate molecules tends to infinity at a pressure close to the saturation state. The BET model is bi-parametric, with $N_{m}$ reflecting the monolayer capacity and C - an energy constant relating to the difference between the free enthalpy of the adsorbate molecules in the pure liquid state and in the first adsorbed layer (Brunauer et al., 1938). The Guggenheim-Anderson-de Boer (GAB) model of multilayer adsorption introduces an additional constant $(\mathrm{K})$. In this model, the layers of adsorbate above the first monolayer are the same, but different from the pure liquid state. The added $\mathrm{K}$ constant reflects the difference between the free enthalpy of the adsorbate molecules in the pure liquid state and in the layers above the monolayer. In the case of $\mathrm{K}$ being equal to 1 , the GAB model is reduced to BET (Anderson, 1946; Van den Berg, 1984). The Aranovich model of adsorption, with respect to the BET model, considers the formation of vacancies in the adsorption layer (Aranovich and Donohue, 1995). The values of the parameters of adsorption models which were calculated for the analysed arctic soils are summarised in Tables 2 and 3.

At $\mathrm{p} \mathrm{p}_{0}{ }^{-1}$ ranging from 0.05 to 0.35 , all the models characterised water vapour adsorption on the surface of the analysed soils very well (Table 3). Moreover, RMS-error values were low. These were $1.30-5.86 \%$ for BET, 0.62$5.78 \%$ for Aranovich and $1.35-7.69 \%$ for GAB models. 

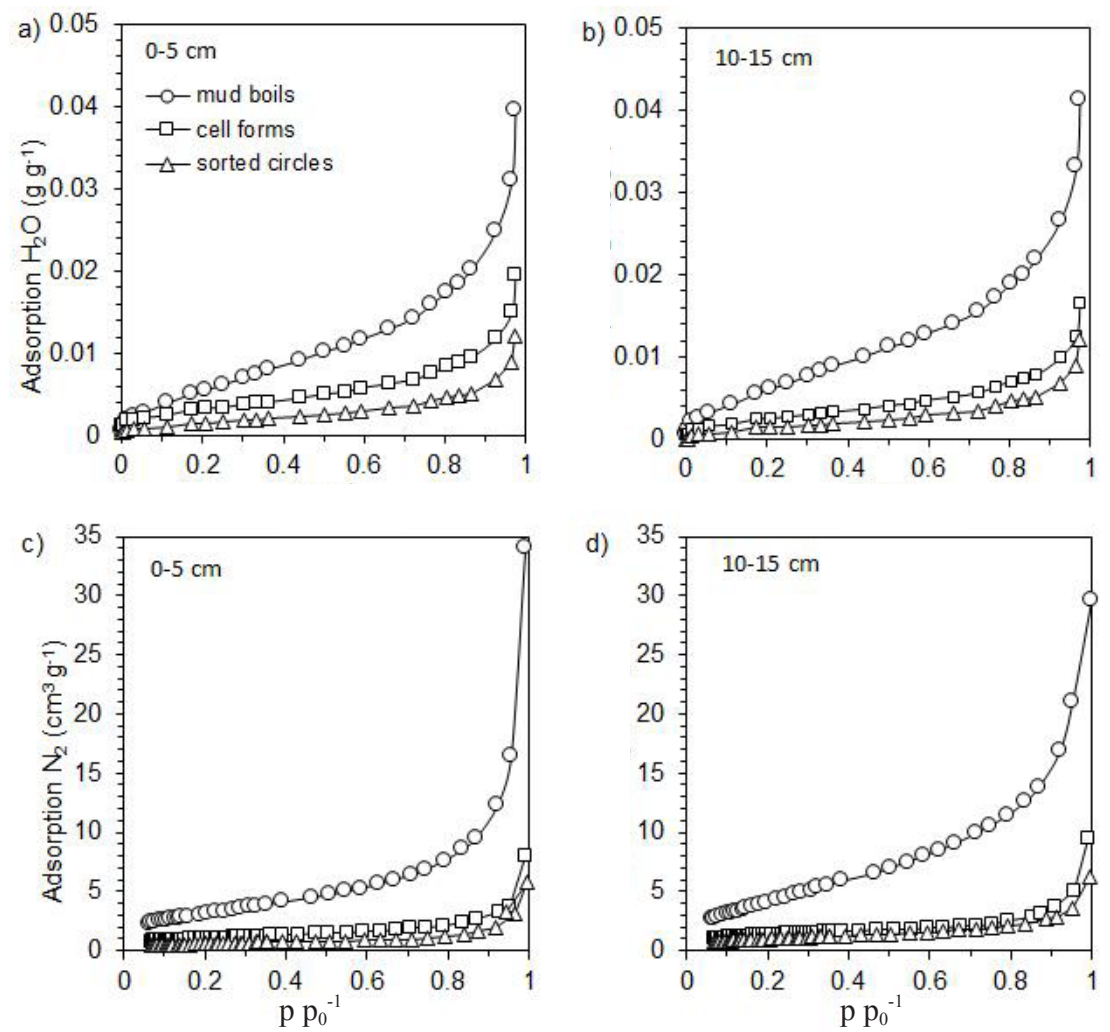

Fig. 1. Isotherms of: a) b) $\mathrm{H}_{2} \mathrm{O}$ and c) d) $\mathrm{N}_{2}$ adsorption obtained for mud boil (MB), cell (CF) and sorted circle (SC) micro-relief forms; for: a) c) 0-5 cm, and b) d) $10-15 \mathrm{~cm}$ depth of soil.

At the same time, $\mathrm{R}^{2}$ values were close to 1.000 . These were equal to 0.962-0.998 for BET, 0.966-0.998 for Aranovich and 0.965-0.999 for GAB. The high values of $\mathrm{C}$ which were obtained for the applied models confirmed type II water vapour sorption isotherms. However, the BET equation described the isotherms at $\mathrm{p} \mathrm{p}_{0}^{-1}<0.6$ well. In the case of a wider range of the relative pressure (0.05-0.86), the RMS error increased to $25.35-46.96 \%$ at $\mathrm{R}^{2}$ values of 0.911-0.933 (Table 4). Other models (Aranovich and GAB) performed better in these conditions. For the Aranovich equation, the RMS errors were $3.09-6.53 \%$ and $\mathrm{R}^{2}$ values were 0.9863-0.9960, whereas for the GAB model, RMS were $1.14-4.13 \%$ and $\mathrm{R}^{2}$ were $0.994-0.999$. This confirmed the broad applicability of the tested models for the description of water vapour adsorption, as provided in the literature (Aranovich and Donohue, 1995; Timmermann, 2003).

For all samples, the monolayer capacity obtained on the basis of desorption was higher than for the adsorption process. Additionally, its values generally changed in the following order: $N_{m \text { Aranovich }}>N_{m \text { GAB }}>N_{m \text { BET. }}$. The constant $\mathrm{C}$ values changed in a reverse order. Similar results were reported by Timmermann (2003) in a comparison of the BET and GAB models. In regard to the type of the analysed material, the monolayer capacity increased in the following order: sorted circles $<$ cell forms $<$ mud boils. For mud boils, the monolayer capacity increased with the increasing depth of the soil profile. For cell forms, there was a reverse relationship, whereas for sorted circles, the depth did not influence the values of this parameter.

The monolayer capacities, which were obtained on the basis of the BET equation at $\mathrm{p} \mathrm{p}_{0}^{-1}$ desorption isotherms ranging from 0.05 to 0.35 (both $\mathrm{H}_{2} \mathrm{O}$ and $\mathrm{N}_{2}$ ), were used for the calculation of specific surface area (Sing et al., 1985). The results are presented in Fig. 2. The specific surface area which was obtained from nitrogen desorption was significantly lower when compared to the specific surface area calculated from water vapour desorption, and when compared to total surface area. It should be noted that water desorption is used to determine 'the internal surface' of soil samples, whereas 'the external surface' is determined based on nitrogen desorption. The highest values of total specific surface area were obtained for mud boils. Lower values were found for cell forms and the lowest for sorted circles. In the case of mud boils and sorted circles, the profile depth did not substantially modify the value of total specific surface area, whereas the $S_{\text {total }}$ of cell forms decreased with an increase in the profile depth.

The investigated soil samples were pre-characterised in terms of their grain size distribution. The correlation between the clay and silt contents in the investigated arctic soils (Melke et al., 2013) and the calculated total specific surface area is presented in Fig. 3. As seen, total specific surface area increased significantly with an increase in the 
T a b l e 3. Parameters obtained for water vapour adsorption/desorption isotherms at $\mathrm{p}_{0}{ }^{-1}$ ranged from 0.05 to 0.35

\begin{tabular}{|c|c|c|c|c|c|c|c|c|}
\hline \multirow{2}{*}{ Model } & \multirow{2}{*}{$\begin{array}{c}\text { Depth } \\
(\mathrm{cm})\end{array}$} & \multirow{2}{*}{ Parameter } & \multicolumn{2}{|c|}{ Mud boils } & \multicolumn{2}{|c|}{ Cell forms } & \multicolumn{2}{|c|}{ Sorted circles } \\
\hline & & & Adsorption & Desorption & Adsorption & Desorption & Adsorption & Desorption \\
\hline \multirow{5}{*}{ BET } & & $\mathrm{N}_{\mathrm{m}}\left(\mathrm{g} \mathrm{g}^{-1}\right)$ & 0.006 & 0.006 & 0.003 & 0.003 & 0.001 & 0.002 \\
\hline & & $\mathrm{C}$ & 13.752 & 24.756 & 45.354 & 105.809 & 23.892 & 118.620 \\
\hline & & $\mathrm{R}^{2}$ & 0.998 & 0.994 & 0.981 & 0.962 & 0.976 & 0.977 \\
\hline & & RMS (\%) & 2.00 & 1.39 & 3.06 & 2.88 & 4.19 & 1.86 \\
\hline & & $\mathrm{N}_{\mathrm{m}}\left(\mathrm{g} \mathrm{g}^{-1}\right)$ & 0.007 & 0.008 & 0.003 & 0.004 & 0.002 & 0.002 \\
\hline \multirow{3}{*}{ Aranovich } & & $\mathrm{C}$ & 8.770 & 12.122 & 20.461 & 23.268 & 13.398 & 24.142 \\
\hline & $0-5$ & $\mathrm{R}^{2}$ & 0.990 & 0.987 & 0.966 & 0.995 & 0.978 & 0.986 \\
\hline & & RMS (\%) & 4.02 & 2.54 & 4.92 & 0.94 & 4.78 & 1.60 \\
\hline \multirow{5}{*}{ GAB } & & $\mathrm{K}$ & 1.130 & 0.970 & 0.932 & 0.816 & 0.747 & 0.910 \\
\hline & & $\mathrm{N}_{\mathrm{m}}\left(\mathrm{g} \mathrm{g}^{-1}\right)$ & 0.005 & 0.006 & 0.003 & 0.004 & 0.002 & 0.002 \\
\hline & & $\mathrm{C}$ & 14.703 & 23.750 & 40.720 & 56.532 & 21.655 & 62.578 \\
\hline & & $\mathrm{R}^{2}$ & 0.999 & 0.994 & 0.981 & 0.985 & 0.979 & 0.986 \\
\hline & & RMS (\%) & 1.35 & 1.44 & 3.24 & 2.06 & 4.38 & 1.38 \\
\hline \multirow{4}{*}{ BET } & & $\mathrm{N}_{\mathrm{m}}\left(\mathrm{g} \mathrm{g}^{-1}\right)$ & 0.006 & 0.007 & 0.002 & 0.003 & 0.001 & 0.002 \\
\hline & & $\mathrm{C}$ & 13.540 & 23.967 & 32.478 & 86.811 & 16.104 & 51.115 \\
\hline & & $\mathrm{R}^{2}$ & 0.992 & 0.994 & 0.974 & 0.962 & 0.963 & 0.983 \\
\hline & & RMS (\%) & 3.93 & 1.30 & 4.24 & 2.70 & 5.86 & 2.18 \\
\hline \multirow{4}{*}{ Aranovich } & & $\mathrm{N}_{\mathrm{m}}\left(\mathrm{g} \mathrm{g}^{-1}\right)$ & 0.008 & 0.009 & 0.003 & 0.004 & 0.002 & 0.002 \\
\hline & & $\mathrm{C}$ & 8.686 & 11.856 & 16.617 & 22.036 & 9.842 & 17.909 \\
\hline & $10-15$ & $\mathrm{R}^{2}$ & 0.981 & 0.989 & 0.967 & 0.979 & 0.973 & 0.998 \\
\hline & & RMS (\%) & 5.78 & 2.23 & 5.62 & 1.81 & 5.14 & 0.62 \\
\hline \multirow{5}{*}{ GAB } & & $\mathrm{K}$ & 1.251 & 0.920 & 0.867 & 0.842 & 0.948 & 0.833 \\
\hline & & $\mathrm{N}_{\mathrm{m}}\left(\mathrm{g} \mathrm{g}^{-1}\right)$ & 0.005 & 0.007 & 0.002 & 0.003 & 0.001 & 0.002 \\
\hline & & $\mathrm{C}$ & 16.012 & 21.806 & 28.786 & 55.641 & 19.751 & 39.251 \\
\hline & & $\mathrm{R}^{2}$ & 0.996 & 0.994 & 0.974 & 0.974 & 0.965 & 0.994 \\
\hline & & RMS (\%) & 2.59 & 1.36 & 4.57 & 2.27 & 7.69 & 1.61 \\
\hline
\end{tabular}


T a b l e 4. Parameters obtained for water vapour adsorption/desorption isotherms at $\mathrm{p} \mathrm{p}_{0}^{-1}$ ranged from 0.05 to 0.86

\begin{tabular}{|c|c|c|c|c|c|c|c|c|}
\hline \multirow{2}{*}{ Model } & \multirow{2}{*}{$\begin{array}{c}\text { Depth } \\
(\mathrm{cm})\end{array}$} & \multirow{2}{*}{ Parameter } & \multicolumn{2}{|c|}{ Mud boils } & \multicolumn{2}{|c|}{ Cell forms } & \multicolumn{2}{|c|}{ Sorted circles } \\
\hline & & & Adsorption & Desorption & Adsorption & Desorption & Adsorption & Desorption \\
\hline \multirow{4}{*}{ BET } & & $\mathrm{N}_{\mathrm{m}}\left(\mathrm{g} \mathrm{g}^{-1}\right)$ & 0.005 & 0.006 & 0.003 & 0.003 & 0.001 & 0.002 \\
\hline & & $\mathrm{C}$ & 22.947 & 85.762 & 141.409 & 149.122 & 49.070 & 311.483 \\
\hline & & $\mathrm{R}^{2}$ & 0.920 & 0.926 & 0.923 & 0.919 & 0.921 & 0.923 \\
\hline & & RMS (\%) & 31.45 & 30.45 & 36.83 & 46.95 & 28.86 & 42.44 \\
\hline \multirow{4}{*}{ Aranovich } & & $\mathrm{N}_{\mathrm{m}}\left(\mathrm{g} \mathrm{g}^{-1}\right)$ & 0.008 & 0.009 & 0.004 & 0.004 & 0.002 & 0.002 \\
\hline & & $\mathrm{C}$ & 7.388 & 9.796 & 16.606 & 30.960 & 8.437 & 23.912 \\
\hline & $0-5$ & $\mathrm{R}^{2}$ & 0.996 & 0.995 & 0.994 & 0.986 & 0.991 & 0.989 \\
\hline & & RMS (\%) & 4.12 & 3.74 & 4.45 & 4.33 & 6.02 & 3.91 \\
\hline \multirow{5}{*}{ GAB } & & $\mathrm{K}$ & 0.775 & 0.793 & 0.775 & 0.737 & 0.809 & 0.750 \\
\hline & & $\mathrm{N}_{\mathrm{m}}\left(\mathrm{g} \mathrm{g}^{-1}\right)$ & 0.007 & 0.008 & 0.003 & 0.004 & 0.002 & 0.002 \\
\hline & & $\mathrm{C}$ & 12.211 & 17.267 & 35.723 & 36.309 & 19.061 & 33.574 \\
\hline & & $\mathrm{R}^{2}$ & 0.999 & 0.999 & 0.998 & 0.999 & 0.996 & 0.997 \\
\hline & & RMS (\%) & 2.83 & 1.77 & 2.73 & 1.14 & 3.48 & 1.98 \\
\hline \multirow{4}{*}{ BET* } & & $\mathrm{N}_{\mathrm{m}}\left(\mathrm{g} \mathrm{g}^{-1}\right)$ & 0.006 & 0.007 & 0.002 & 0.003 & 0.001 & 0.002 \\
\hline & & $\mathrm{C}$ & 23.755 & 26.833 & 272.016 & 132.274 & 30.350 & 53.621 \\
\hline & & $\mathrm{R}^{2}$ & 0.917 & 0.930 & 0.911 & 0.918 & 0.933 & 0.918 \\
\hline & & RMS (\%) & 32.14 & 38.31 & 31.45 & 42.19 & 25.35 & 41.61 \\
\hline \multirow{4}{*}{ Aranovich } & & $\mathrm{N}_{\mathrm{m}}\left(\mathrm{g} \mathrm{g}^{-1}\right)$ & 0.008 & 0.010 & 0.003 & 0.004 & 0.002 & 0.002 \\
\hline & & $\mathrm{C}$ & 7.703 & 9.312 & 11.816 & 19.438 & 6.222 & 15.091 \\
\hline & $10-15$ & $\mathrm{R}^{2}$ & 0.995 & 0.995 & 0.991 & 0.989 & 0.990 & 0.989 \\
\hline & & RMS (\%) & 4.82 & 3.09 & 5.52 & 3.72 & 6.53 & 3.93 \\
\hline \multirow{5}{*}{ GAB } & & $\mathrm{K}$ & 0.768 & 0.782 & 0.787 & 0.751 & 0.838 & 0.748 \\
\hline & & $\mathrm{N}_{\mathrm{m}}\left(\mathrm{g} \mathrm{g}^{-1}\right)$ & 0.007 & 0.008 & 0.003 & 0.003 & 0.001 & 0.002 \\
\hline & & $\mathrm{C}$ & 12.315 & 17.292 & 24.929 & 29.221 & 15.634 & 21.554 \\
\hline & & $\mathrm{R}^{2}$ & 0.998 & 0.999 & 0.997 & 0.998 & 0.994 & 0.996 \\
\hline & & RMS (\%) & 3.76 & 1.51 & 3.63 & 1.88 & 4.13 & 2.30 \\
\hline
\end{tabular}

$* N_{m}$ and $\mathrm{C}$ for $\mathrm{p} \mathrm{p}_{0}{ }^{-1}$ ranged from 0.05 to 0.60 . 

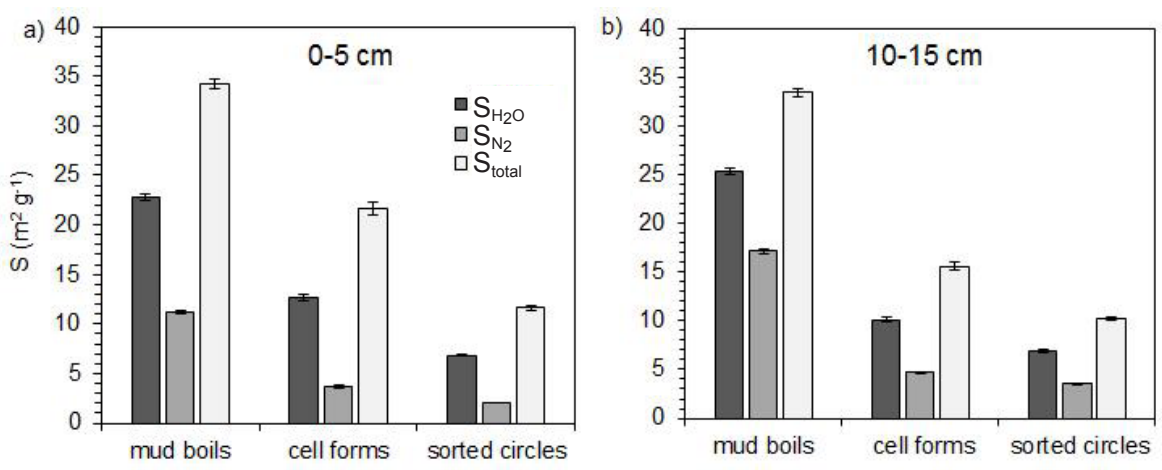

Fig. 2. Specific surface area calculated using the BET model at $\mathrm{p} \mathrm{p}_{0}{ }^{-1}$ ranged from 0.05 to 0.35 for the investigated arctic soils for two soil depths: a) $0-5 \mathrm{~cm}$, b) $10-15 \mathrm{~cm}$.
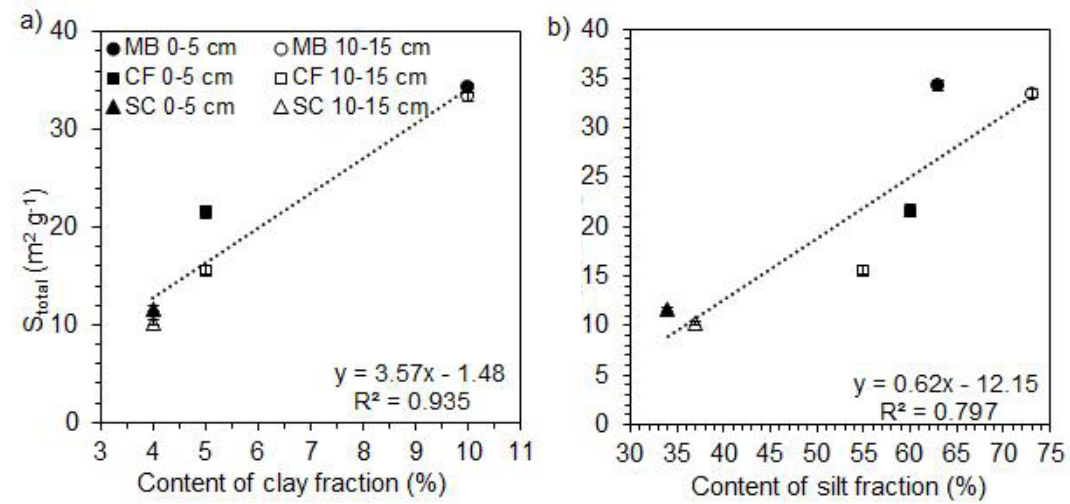

Fig. 3. Relationship between the total specific surface area of investigated soils and the content of a) clay and b) silt fraction.

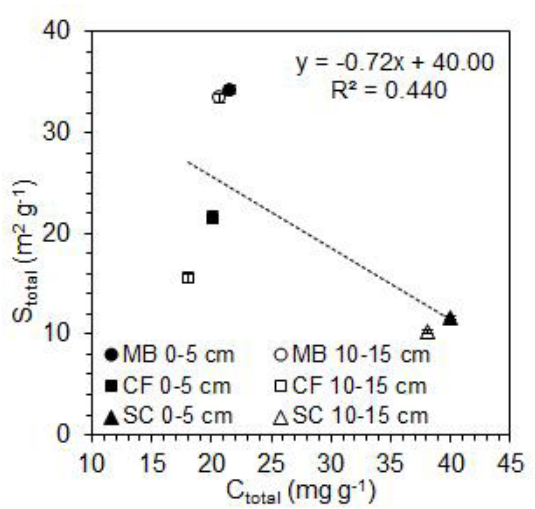

Fig. 3. Relationship between total specific surface area and $C_{\text {total }}$ content.

content of both clay and silt fractions. However, a higher determination coefficient was obtained for the correlation with the amount of the fraction of smallest particles.

It is known that organic matter influences the specific surface area of soil (Ding Fei et al., 2013; Skic et al., 2016; Sokołowska et al., 2009; Xiaojun Zhu et al., 2014). However, the effect of soil organic matter on specific surface area is generally not unambiguous (Sokołowska et al., 2009; Xiaojun Zhu et al., 2014). Since specific surface area includes inner and external surface areas, and the sum of both is total surface area, this notion is mainly affected by clay mineral content. Moreover, external surface area is positively correlated with TOC (total organic carbon) in soils and sediments. Indeed, a positive correlation has also been found between total surface area and TOC in black shale and continental margin sediments, while a negative correlation between TOC and external surface area was observed in mudstones (Sokołowska et al., 2004). In arctic soils, a positive correlation is found between clay $\left(\mathrm{R}^{2}\right.$ $=0.935)$ and silt (0.797) content and specific surface area; however, no correlation between the total carbon amount and the values of specific surface area has been found. The results of our study are presented in Fig. 4. A trend can be seen in that total specific surface area decreases as the content of carbon increases. However, this relationship was not statistically significant. The amount of organic carbon in the investigated soils increased with an increase in the depth, but this did not depend on the content of clay $\left(\mathrm{R}^{2}=0.014\right)$, silt $\left(\mathrm{R}^{2}=0.013\right)$ and sand $\left(\mathrm{R}^{2}=0.014\right)$ fractions. Furthermore, the content of organic carbon did not modify the value of total specific surface area $\left(\mathrm{R}^{2}=0.0008\right)$. Indeed, the total amount of carbon in samples decreased with an increase in the content of clay $\left(\mathrm{R}^{2}=0.305\right)$ and silt 
$\left(\mathrm{R}^{2}=0.788\right)$, and increased with an increase in the amount of sand $\left(\mathrm{R}^{2}=0.732\right)$. Organic matter in natural soils and sediments can be divided into different organic components - e.g. soluble, non-soluble and amorphous organic matter. Humic acids in Spitzbergen tundra soils have many properties which are characteristic for young humic acids, and are rather similar to fulvic acid (Dziadowiec et al., 1994).

In analysing the above presented results, it is evident that they are in agreement with our previous results related to water characteristics, i.e. water curves retention and water conductivity (Melke et al., 2013; Witkowska-Walczk et al., 2014). So, when the specific surface area determined by water vapour is the largest (mud boils) - the water retention is the highest, whereas the lowest values of $\mathrm{S}_{\mathrm{H}_{2} \mathrm{O}}$ are accompanied by the lowest water retention. This relationship is the same for both investigated depths, $0-5$ and $10-15 \mathrm{~cm}$. The differences are especially clear for low water potentials (lower than $-100 \mathrm{KJ} \mathrm{m}^{-3}$ ). Similar relationships can be found for $S_{\text {total }}$ and $S_{\mathrm{N}_{2}}$. Still, water conductivity and specific surface area values are more complex than those mentioned above. The differences between the values of water conductivity coefficients for the investigated geomorphological arctic forms are not as clear as for water retention. At the highest soil water potential level for both depths, water movement is the most significant in mud boils and cell forms, i.e. in forms with substantial specific surface areas. Different phenomena are observed at lower values of soil water potential, i.e. in the first layer, water movement is the highest in cell forms, and is the lowest in mud boils, whereas in the deeper layer, water moves much quicker in sorted circles (the lowest values of specific surface area) than in cell forms and mud boils.

\section{CONCLUSIONS}

1. The values of total specific surface area were the highest in Cryosols on mud boils, lower on cell forms, and the lowest on sorted circles. Such tendency was observed for the values determined separately by water vapour and nitrogen adsorption.

2. The differences in the values of specific surface area at two investigated layers were small.

3. High determination coefficients were obtained for relationships between specific surface areas and clay and silt content in Cryosols.

4. No statistically significant correlation between the total carbon amount and the values of specific surface area in Cryosols has been found.

Conflict of interest: The Authors declare they have no conflict of interest.

\section{REFERENCES}

Anderson R.B., 1946. Modifications of the Brunauer, Emmett and Teller equation. J. Am. Chem. Soc., 68, 686-691.
Angiel M., 1994. Heat flux in selected polar soil in spring and summer (Spitsbergen). Polish Polar Res., 15, 51-70.

Aranovich G.L. and Donohue M.D., 1995. A new approach to analysis of multilayer adsorption. J. Coll. Interface Sci., 173, 515-520.

Bockheim J.G., 2015. Cryopedology. Springer Press, HeidelbergNew-York-Dordrecht-London.

Brunauer S., Emmet P., and Teller E., 1938. Adsorption of gases in multimolecular layers. J. Am. Chem. Soc., 60, 309-319.

Ding Fei, Cai JinGong, Song MingShui, and Yuan Peng, 2013. The relatiobship between organic matter and specific surface area in $<2 \mu$ m clay size fraction of muddy source rock. China Earth Sci., 56, 1343-1349.

Dziadowiec H., Gonet S., and Plichta W., 1994. Properties of humic acids of Arctic tundra soils in Spitsbergen. Polish Polar Res., 15, 17-81.

Gregg S.J. and Sing K.S.W., 1978. Adsorption, surface area and porosity. Academic Press, London-New York.

IUSS Working Group WRB, 2007. World Reference Base for Soil Resources-2006 (first update-2007). World Soil Resources Reports, No. 103, FAO Press, Rome, Italy.

Jahn R., Blume H.P., Asio V.B., Spaargaren O., and Schad P., 2006. Guidelines for Soil Description. FAO-ISRIC Press, Rome, Italy.

Klimowicz Z., Chodorowski J., Melke J., Uziak S., and Bartmiński P., 2013. Soils. In: Geographical Environment of NW Part of Wedel Jarlsberg Land (Spitsbergen, Svalbard) (Eds P. Zagórski, M. Harasimiuk, J. Rodzik), UMCS Press, Lublin, Poland.

Kutilek M. and Nielsen D.R., 2010. Facts About Global Warming. Catena Press, Reiskirchen, Germany.

Kutilek M. and Nielsen D.R., 2015. Soil. The Skin of the Planet Earth. Springer Press, Dordrecht-Heidelberg-LondonNew-York.

Lal R. and Shukla M.K., 2004. Principles of Soil Physics. Dekker Press, New York - Basel.

Melke J., Witkowska-Walczak B., and Bartmiński P., 2013. Water retention of arctic zone soils (Spitsbergen). Int. Agrophys., 27, 439-444.

Petersen L.W., Moldrup P., Jacobsen O.H., and Rolston D.E., 1996. Relation between specific surface area and soil physical and chemical properties. Soil Sci., 161, 9-21.

PN-Z-19010-1, 1999. Soil quality. Determination of specific surface area of soil. Measurement by water vapour sorption.

Ryżak M. and Bieganowski A., 2013. Methodological aspects of determining soil particle-size distribution using the laser diffraction method. J. Plant Nutr. Soil Sci.,174, 624-633.

Sing K.S.W., Everett D.H., Haul R.A.W., Moscou L., Pierotti R.A., Rouquerol J., and Siemieniewska T., 1985. Reporting physisorption data for gas/solid systems with special reference to the determination of surface area and porosity (Recommendations 1984). International Union of Pure and Applied Chemistry. Physical Chemistry Division Commission on Colloid and Surface Chemistry Including Catalysis. Pure and Appl. Chem., 57, 603-619.

Skic K., Boguta P., and Sokołowska Z., 2016. Analysis of the sorption properties of different soils using water vapour adsorption and potentiometric titration methods. Int. Agrophys., 30, 369-374. 
Sokołowska Z., 2011. Surface area of soils and plants. In: Encyclopedia of Agrophysics (Eds J. Gliński, J. Horabik, J. Lipiec). Springer Press, Dordrecht-Heidelberg-LondonNew York.

Sokołowska Z., Hajnos M., Elias E.A., and Alaily F., 2004. Characteristics of the surface area of Vertisols from the Gezira region in Sudan. International Agrophysics, 18, 83-90.

Sokołowska Z., Warchulska P., and Sokołowski S., 2009. Trends in surface fractal parameters caused by accumulation of soil organic matter as resulting from the analysis of water vapor adsorption isotherms. Ecological Complexity, 6, 254-262.

Stanich N.A., 2013. Soil physical property characteristics and chronosequence analysis about a glacial fore-field in Skaftafellsjökul, Iceland. Master's Thesis. The Oslo State Univ., Norway.

Szymański W., Skiba S., and Wojtuń B., 2013. Distribution, genesis, and properties of Arctic soils: a case study from the Fuglebekken catchment, Spitsbergen. Polish Polar Res., 34, 289-304.

Tedrow J.F.C., 1977. Soils of the Polar Landscape. Rutgers Univ. Press, New Brunswick, NJ.

Timmermann E.O., 2003. Multilayer sorption parameters: BET or GAB values? Colloids and Surfaces A: Physicochem. Eng. Aspects, 220, 235-260.
Trenberth K.E., Jones P.D., Ambenje P., Borariu R., Easterling D., Klein Tank A., Parker D., Rahimzadeh F., Renwick J.A., Rusticucci M., Soden B., and Zhai P., 2007. Observations:surface and atmospheric climate change. In: IPCC Climate Change, the Physical Science Basis, EU Press, Brussels, Belgium.

Van den Berg C., 1984. Description of water activity of foods for engineering purposes by means of the GAB model of sorption. In: Engineering and food (Ed. B.M. McKenna) Elsevier, London, UK.

Walker T.R., 2012. Properties of selected soils from the sub-Arctic region of Labrador, Canada. Polish Arctic. Res., 22, 207-224

Washburn A.L., 1980. Geocryology. Wiley Press, New York, USA.

Witkowska-Walczak B., Sławiński C., Bartmiński P., Melke J., and Cymerman J., 2014. Water conductivity of arctic zone soils (Spitsbergen). Int. Agrophys., 28, 539-535.

Xiaojun Zhu, Jingong Cai, Xuejun Wang, Jingqiao Zhang, and Jinli Xu., 2014. Effects of organic components on the relationships between specific surface areas and organic matter in mudrocks. Int. J. Coal Geology, 133, 24-34.

Ziaja W., 2004. Spitsbergen landscape under 20th century climate change: Sorkapp Land. Ambio, 33, 295-299. 